\title{
Effect of Cassava (Manihot esculenta Crantz: Euphorbiaceae) Starch on the Stabilization of Malagasy Lateritic Soil
}

\author{
Harinivo Olsynthique Razanajatovo ${ }^{1}$, Serge Ravelomanantsoa ${ }^{2}$, Elise Octavie \\ Rasoazanany $^{3}$, Aristote Matondo ${ }^{4}$, Colette Masengo Ashande ${ }^{5}$, Muhammad Ridwan $^{6}$, \\ Koto-te-Nyiwa Ngbolua ${ }^{7}$, Robijaona Rahelivololoniaina Baholy ${ }^{8}$ \\ ${ }^{1,2,8}$ Doctoral School "Process Engineering and Industrial, Agricultural and Food Systems" \\ University of Antananarivo, Polytechnic High School, Antananarivo, Madagascar \\ ${ }^{3}$ Department of Fluorescence X and Environment, National Institute of Nuclear Sciences and Techniques, \\ Antananarivo, Madagascar \\ ${ }^{4}$ Department of Chemistry, Faculty of Science, University of Kinshasa, Kinshasa, Democratic Republic of the \\ Congo \\ ${ }^{5,7}$ Department of Environmental Sciences, Faculty of Science, University of Gbado-Lite, Gbado-Lite, Democratic \\ Republic of the Congo \\ ${ }^{6}$ Universitas Islam Negeri Sumatera Utara, Medan, Indonesia \\ ${ }^{7}$ Department of Biology, Faculty of Science, University of Kinshasa, Kinshasa, Democratic Republic of \\ the Congo \\ holyrobi@gmail.com
}

\begin{abstract}
Laterite is one of the most widespread raw materials, especially in Madagascar. Its valorization as a building material would help to solve many socio-economic problems in Madagascar as well as in Africa. The use of this type of material fits well within the framework of high environmental quality, since the process uses an abundant material that does not require too much energy for its manufacture because it is dried in the open air. The aim of this work was to stabilize the laterite with cassava starch. The valorization of the latter would contribute to the development of new building materials. The study focuses on the mechanical characterization of specimens made with Vontovorona laterite in different proportions, which goes hand in hand with the determination of the physico-chemical parameters of the starch. To make specimens, we used techniques such as extraction, sieving, heating, laterite-stabilizing dosage, mixing, rotting, moulding, clamping, demoulding, drying. The results obtained show that the best stabilizing material is obtained if 15\% of starch is mix to lateritic soil. The compressive strength in the dry state of the test specimens (samples) gave a significantly interesting result with a value of 54.8 bars (85\% laterite with $15 \%$ starch). Thus the use of starch as a stabilizer in construction gave satisfactory results. This ecofriendly process, simple in its steps and practice, should be popularized among artisanal brick makers. Thus, replacing proportions of the Portland cement in soil stabilization with Cassava starch will reduce the overall environmental impact of the stabilization process.
\end{abstract}

Keywords: laterite; stabilization; starch; cassava; compressive strength; Madagascar

\section{Introduction}

The population continues to grow in number and requires a reception infrastructure to avoid settlement in shantytowns and create a vulnerable layer when natural disasters occur. Today with clay from rice fields, bricks are still made with rudimentary ancestral techniques as in many African countries [1]. This problem always leads us to look for new or adequate materials, more reliable, cheaper, more resistant and even biodegradable.

Laterites, lateritic clays, or lateritic soils (Figure 1a) are a large family of soils (generally of red colour) which form in humid tropical and subtropical regions and which result from a particular weathering process [2]. To the soil engineer, the word "soil" means a material which is used in any kind of civil engineering job, either as foundation material to support the load exerted by structures, or as construction material itself, as in the case of highway constructions. For this reason, lateritic soils represent an alternative as building 
material and are widely used around the world mainly in Africa (Figure 1b). They are very different from other soils, because they have much higher content of iron and aluminum oxides (sesquioxide) and often contain some secondary minerals such as goethite and hematite [3-4], as well large amounts of quartz and kaolinite.

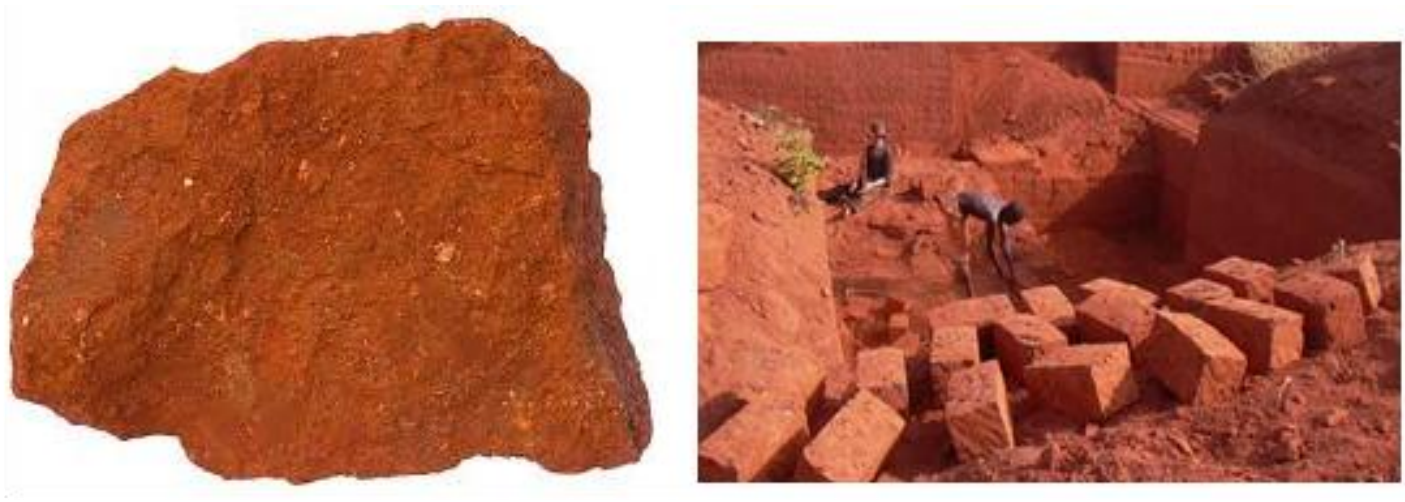

Figure 1. Laterite (a) and House Foundation using Lateritic Bricks (b)

There are numerous hypotheses on the genesis of laterites. Nevertheless, the most common hypothesis is that laterite can be formed from any type of rock (silicate, carbonate, etc), but only if the climate is hot and humid for an extended period [5]. During the weathering process which is very much dependent on the environmental conditions in which soils are occurring, the more unstable basic minerals disappear (e.g feldspars), and the more soluble ions escape in solution.

The stability of lateritic soils is a very important issue and depends essentially on the types of minerals that are contained in the soils. Some minerals such as halloysite and montmorillonite found in Hawaiian lateritic soils are known as being formed in the very early stages of weathering and they are not stables [6]. The iron and aluminum oxides contained in lateritic soils play a crucial role for their stabilization and thus, in the formation and stabilization of large-size aggregates [7]. To obtain a building material with better properties than the original soil, several products are mixed with the soil. The most commonly used are cement and lime, which are very expensive and luxury products. Thus, there is need to search for alternative methods of making use of cassava starch.

The valorization of natural substances such as cassava is one of the ideal solutions. Cassava (roots) is a product of agriculture in large quantities in several regions in Madagascar. The production of cassava in Madagascar is estimated in 2018 at more than 4.5 million tons [8]. It is generally practiced by peasants, in small plantations not exceeding 1 ha. The province of Fianarantsoa is the leading producer of fresh cassava at the national level, and supplies Antananarivo. It also supplies other regions such as the south of the island, which still has to bring in Tsiroanomandidy and Anjozorobe in times of drought. For this reason, we have chosen the theme "valorization of cassava used as laterite stabilizer". The aim of this research is to transform cassava starch into a stabilizer that can improve the mechanical resistance of the laterite brick and reduce the emission of $\mathrm{CO}_{2}$ gas and consequently global warming in the world. This vision is in line with the meeting of the member states of the United Nations Framework Convention on Climate Change. 


\section{Material and Methods}

\subsection{Presentation of Cassava Starch}

Starch consists mainly of glucidic fractions.

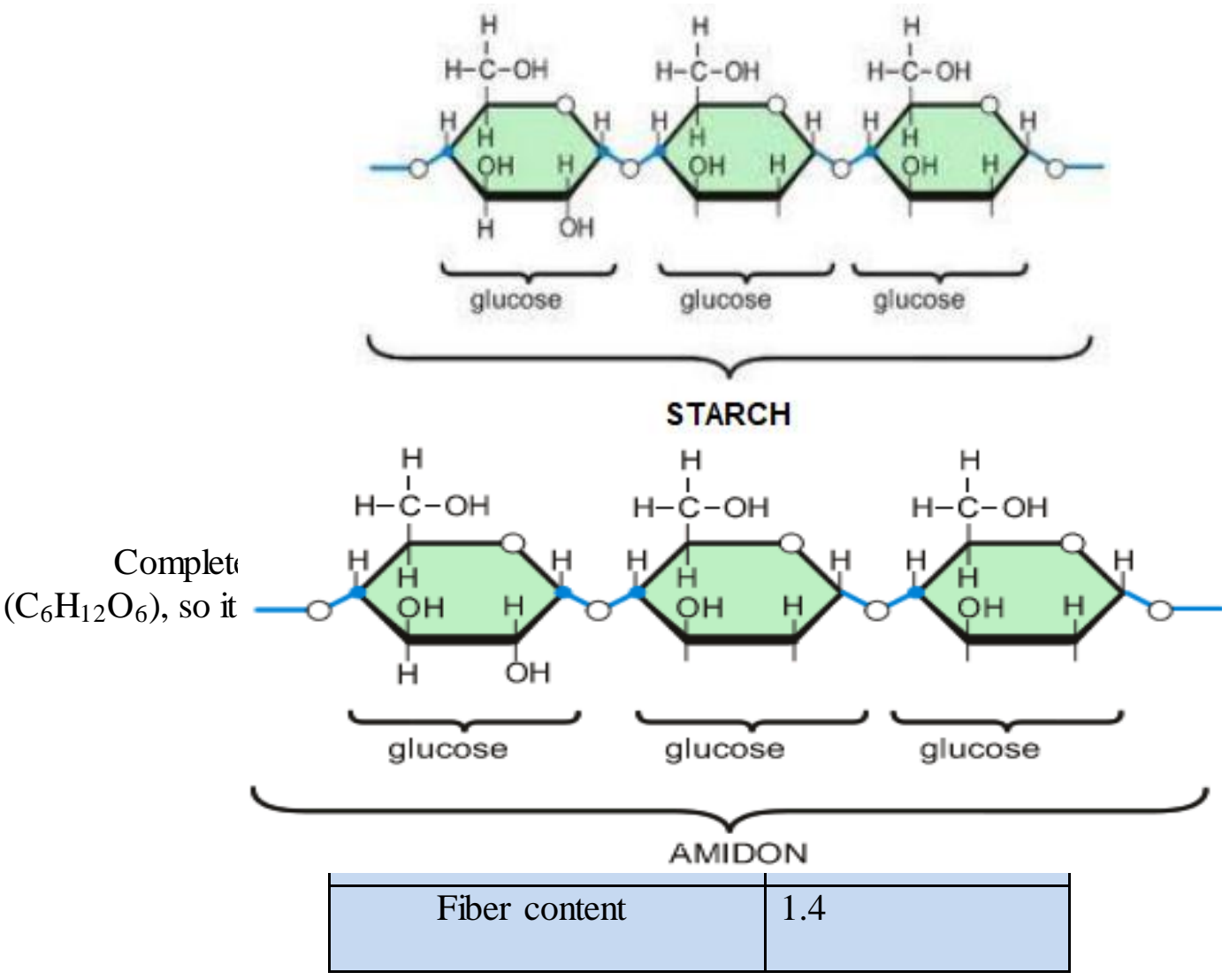

molecules

\subsection{Vontovorona Laterite Data}

The structure of the laterites is described as follows:

- Primary structure: iron oxide $\left(\mathrm{Fe}_{2} \mathrm{O}_{3}\right)$

- Secondary structure: clay

- Tertiary structure: magnetite $\left(\mathrm{Fe}_{3} \mathrm{O}_{4}\right)$

- Quaternary structure: quartz $\left(\mathrm{SiO}_{2}\right)$

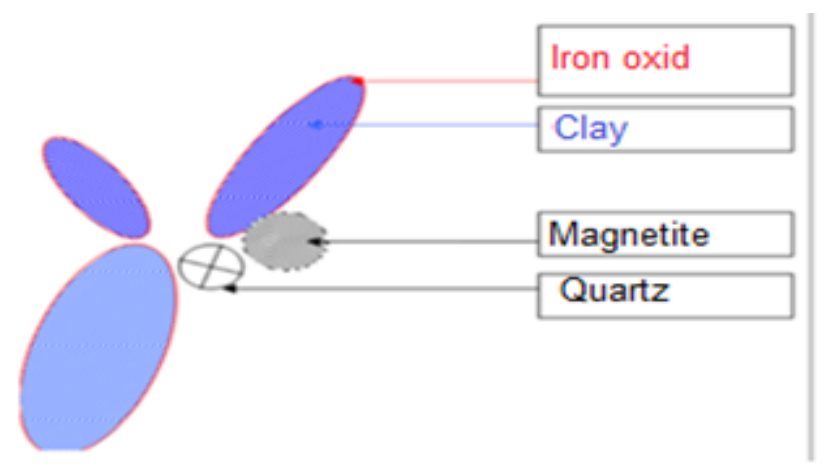

Figure 3. Structure of Laterite 
The chemical composition of the soil used in this study was performed by alkaline fusion method in order to determine the major elements according to NF ISO 14869-2 [11]. The chemical analysis reveals the presence of oxides of silicon, aluminium, iron, titanium, etc (Table 2).

Table 2. Results of the Analysis of the Chemical Constituents of Vontovorona Laterite

\begin{tabular}{|l|c|}
\hline Constituents & Content (\%) \\
\hline $\mathrm{SiO}_{2}$ & 31.54 \\
\hline $\mathrm{Al}_{2} \mathrm{O}_{3}$ & 25.94 \\
\hline $\mathrm{Fe}_{2} \mathrm{O}_{3}$ & 26.01 \\
\hline $\mathrm{TiO}_{2}$ & 4.40 \\
\hline $\mathrm{CaO}$ & Trace \\
\hline $\mathrm{MgO}$ & Trace \\
\hline $\mathrm{SO}_{3}$ & Trace \\
\hline $\mathrm{K}_{2} \mathrm{O}$ & Trace \\
\hline $\mathrm{Cr}_{2} \mathrm{O}_{3}$ & Trace \\
\hline $\mathrm{MnO}_{\mathrm{Na}} \mathrm{O}$ & 0.21 \\
\hline $\mathrm{P}_{2} \mathrm{O}_{5}$ & 0.09 \\
\hline $\mathrm{Loss}$ of fire & 0.51 \\
\hline \multicolumn{2}{|l}{} \\
\hline
\end{tabular}

\subsection{Methodology}

\section{a. Stabilization Objectives}

Stabilizing laterite means modifying the local soil so that it is best suited to the requirements involving modification of the properties of a land-water-air system to obtain permanent properties compatible with a given application.

The main objectives are to:

- Obtain better mechanical characteristics: increase dry and wet compressive strength, tensile and shear strength;

- Obtain better cohesion ;

- Improve resistance to wind and rain erosion: reduce surface abrasion and waterproof.

\section{b. Types of Stabilization}

Two possible ways to stabilize the lateritic soils are used in this study: mechanical stabilization and chemical stabilization.

\section{Mechanical stabilisation}

The properties of the earth were modified by intervening on its structure. It is the compaction of the earth that modifies its density, compressibility, permeability and porosity.

\section{Chemical stabilisation}

Laterite is added to other materials or chemicals that modify its properties. The modifications result from physico-chemical reactions between the active constituents of laterite and the materials, leading to the formation of new phases within the texture and maximum coating of the inert grains.

\section{c. Test Tubes Manufacturing}

\section{Use of earth-stabilizer mixture}

This step is very complex, since, on the one hand, the effectiveness of stabilization depends very strongly on the quantity of starch to be used, and on the other hand, the performance of the finished samples varies with its content. The different stages of stabilization are: laterite extraction, sieving, heating, laterite-stabilizer dosage, mixing, rotting, moulding, clamping, demoulding and drying, as can be seen in Figure 4. 


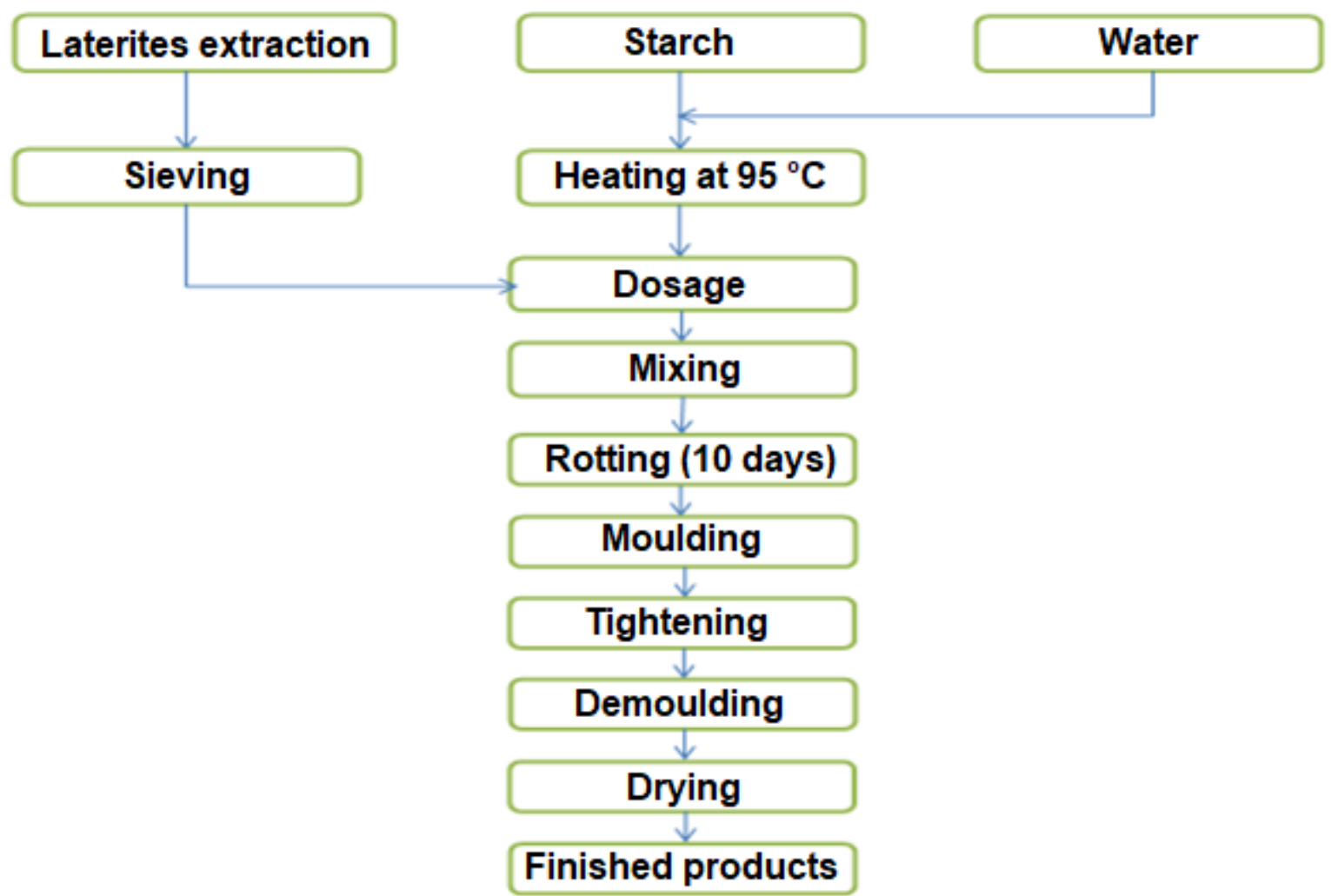

Figure 4. Diagram of Laterite Stabilization by Starch

\section{- Laterite Extraction}

Samples were collected from the Vontovorona Campus enclosure (Madagascar) at a depth of $1 \mathrm{~m}$ at Laborde coordinates; $\mathrm{x}=791$. 500; $\mathrm{y}=504.500$. Laterite is extracted at a depth of $1 \mathrm{~m}$ with a shovel and manually. Attempts are made to clear the soil of any organic debris that may be with it and that may interfere with the implementation and composition envisaged for the bricks.

After being extracted from the quarry, the soil is unloaded and stored in a spacious and wellventilated area for easy handling.

\section{- Sieving}

Before this operation, the laterite was dried in an oven at $120^{\circ} \mathrm{C}$ for two hours. Then it was sieved with an AFNOR sieve with a mesh size of $1 \mathrm{~mm}$. The particles passing through the mesh of this sieve are collected.

\section{- Drying}

Starch can be heated with water at a temperature of $95^{\circ} \mathrm{C}$ to obtain the maximum viscosity of the starch.

\section{- Dosage}

This is the mixing of laterite with stabilizer and water. This method uses weighing equipment that must be accurate to within 10 to $50 \mathrm{~g}$ depending on the quantities weighed. The smaller the quantities, the more accurate the scale must be.

- Kneading

There are two ways to do the mixing. 


\section{$\rightarrow$ Dry Kneading}

Dry mixing is intended to homogenize the soil-stabilizer mixture. Good dry mixing should be carried out and the minimum mixing time of 3 to 4 minutes should be respected, otherwise the effectiveness of the stabilization may be reduced. The decrease in performance can reach about $20 \%$.

\section{- Wet kneading}

The mixture is then moistened to the optimum moulding water content. This water content also varies with the nature of the soil and the stabilizer to be used. An error in water content of 1 to $2 \%$ can lead to a decrease of 2 to $10 \%$ in the dry density of the blocks.

- Rotting

Rotting consists in letting the mixture rest for 10 days in order to increase the plasticity and homogeneity of the mixture by treating the pasta by exposure to humidity.

\section{- Moulding}

The dough is poured into a test tube (mould) and kneaded into the desired shape. The use of release oil is necessary to facilitate the demoulding process and to avoid sticking to the mould wall. This can be done using running oil or even water. Both sides of the specimens must be surface-prepared (flat side and bottom side of the mould). The crushing test shall be carried out on the flattened side, i.e. in the same direction as the specimens are made.

\section{- Tightening}

The purpose of clamping is to rearrange the soil particles so that they can bind together well. This leads on the one hand to an increase in the density of the compact assembly, and on the other hand to a decrease in its permeability, all three of which are very important characteristics in geotechnics.

\section{- Demoulding}

Demoulding is carried out after the dough has been tightened. This must be done carefully, meticulously and thoroughly.

\section{- Drying}

Drying is done in the shade but not in the sun: this is to limit the accelerated shrinkage of the laterite. In addition, the specimens or samples must be protected from all weather conditions to promote their maturation. A spacious and well-ventilated place must be found to dry them. 


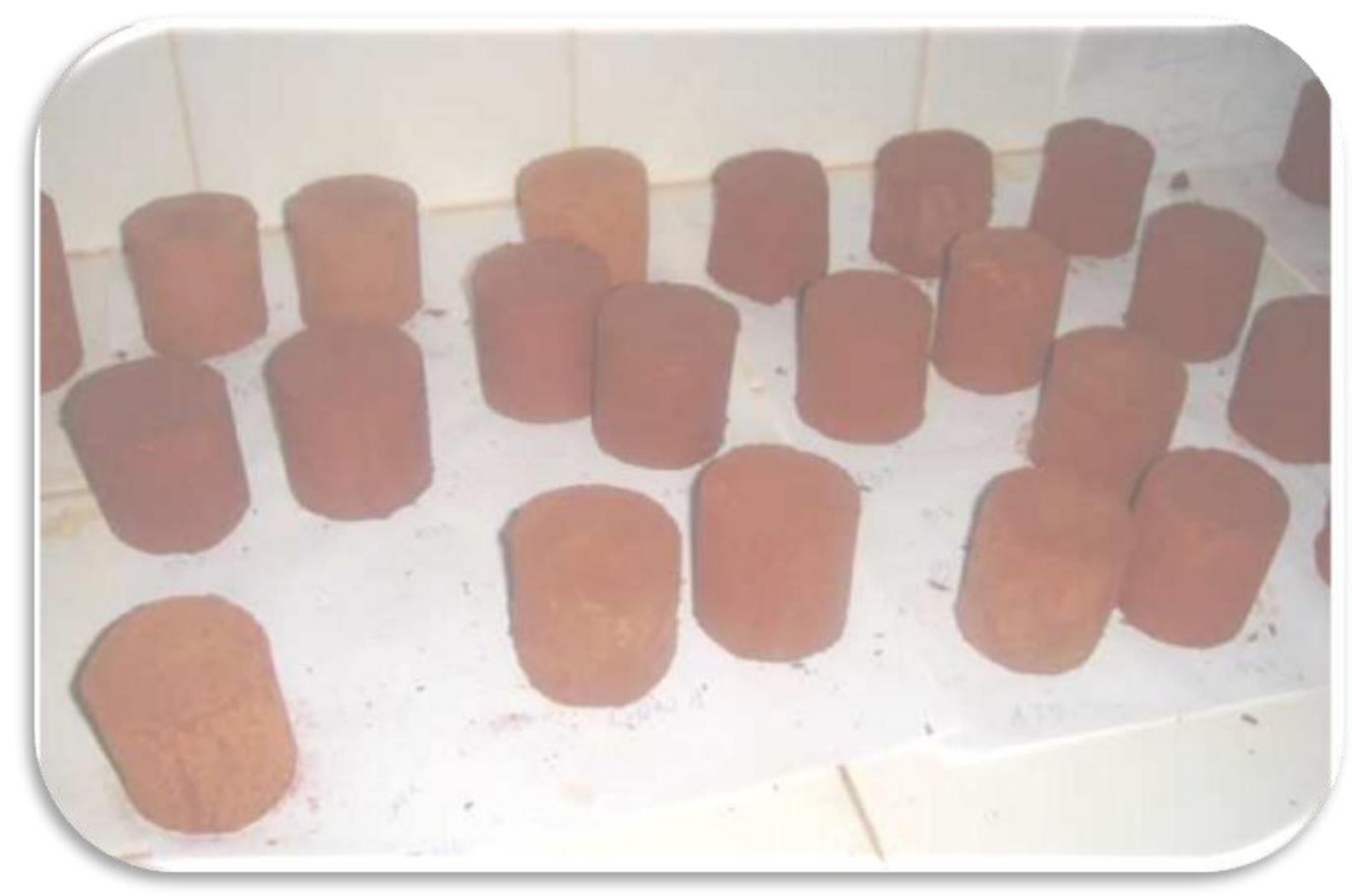

Figure 5. Test Tubes Made of Stabilized Laterites

\section{d. Characterization of Finished Products}

The purpose of these tests is to determine certain performances and properties of the materials in order to assign them appropriate and adequate uses.

The basic tests for the characterization of finished products are the withdrawal; the porosity and the crush resistance. In order to clearly distinguish the samples from each other, the following notations have been adopted, specifying the nature and proportion of the stabilizer used. LS X: Laterite with X\% of starch (LS 00: L with 0\% of starch; LS 05: L with 5\% of starch; LS 10: L with $10 \%$ of starch; LS 15: L with $15 \%$ of starch; LS 20: L with $20 \%$ of starch).

\section{Results and Discussion}

\subsection{Withdrawal}

Shrinkage is expressed by the variation in length and diameter during the drying of the specimens. The length of the fresh shaped product is then measured. Another measurement is performed after 14 days of drying.

Either: $\quad R(\%)=\frac{d_{h}-d_{s}}{d_{h}} \times 100^{\mathrm{r}} \quad R(\%)=\frac{L_{1}-L_{2}}{L_{2}} \times 100$

With $\mathrm{L}_{1}$ : fresh product length; $\mathrm{L}_{2}$ : length of the completely dry product; $\mathrm{d}_{\mathrm{h}}$ : fresh product diameter and $\mathrm{d}_{\mathrm{s}}$ : diameter of the completely dry product. The linear shrinkage of the bricks was measured on day 14 . The results obtained are presented in the figure 6 . 


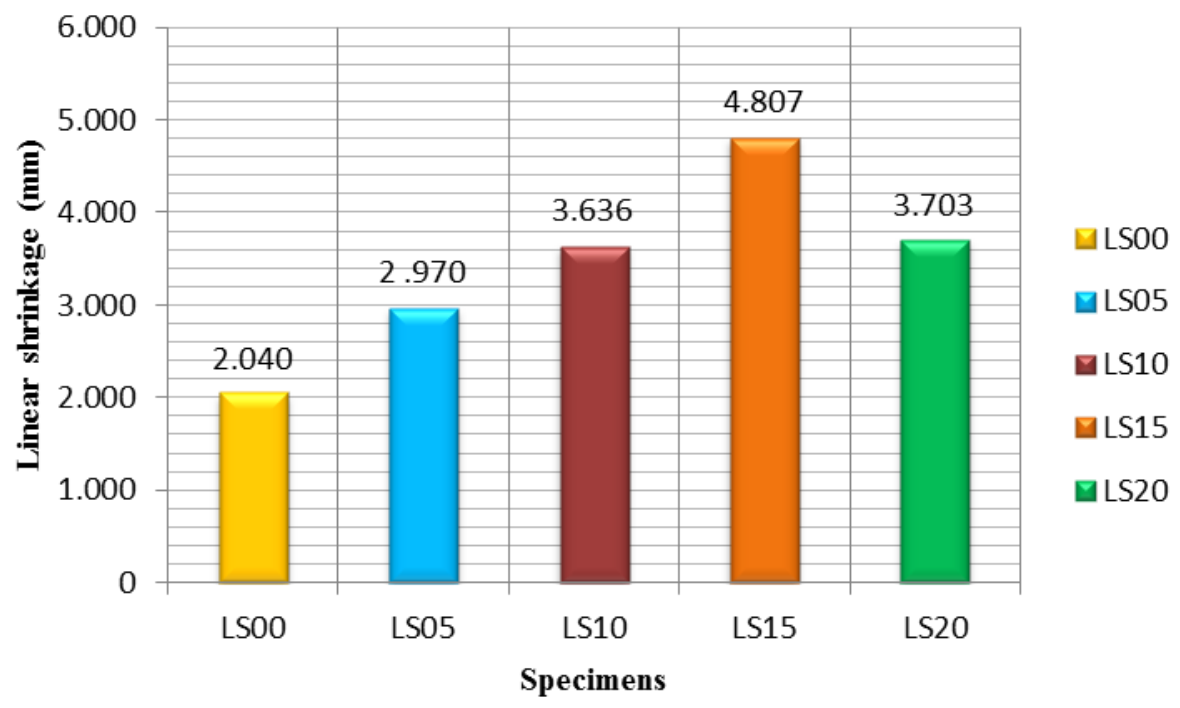

Figure 6. Variations in Linear Shrinkage of Specimens

\subsection{Porosity}

It is the percentage of the amount of water absorbed by the material during its immersion for 24 hours (Figure 7). It is defined by the relationship:

$$
p=\frac{M_{h}-M_{s}}{M_{s}} \times 100
$$

with $\mathrm{p}=$ porosity; $\mathrm{M}_{\mathrm{h}}=$ wet material mass and $\mathrm{M}_{\mathrm{S}}=$ dry material mass.

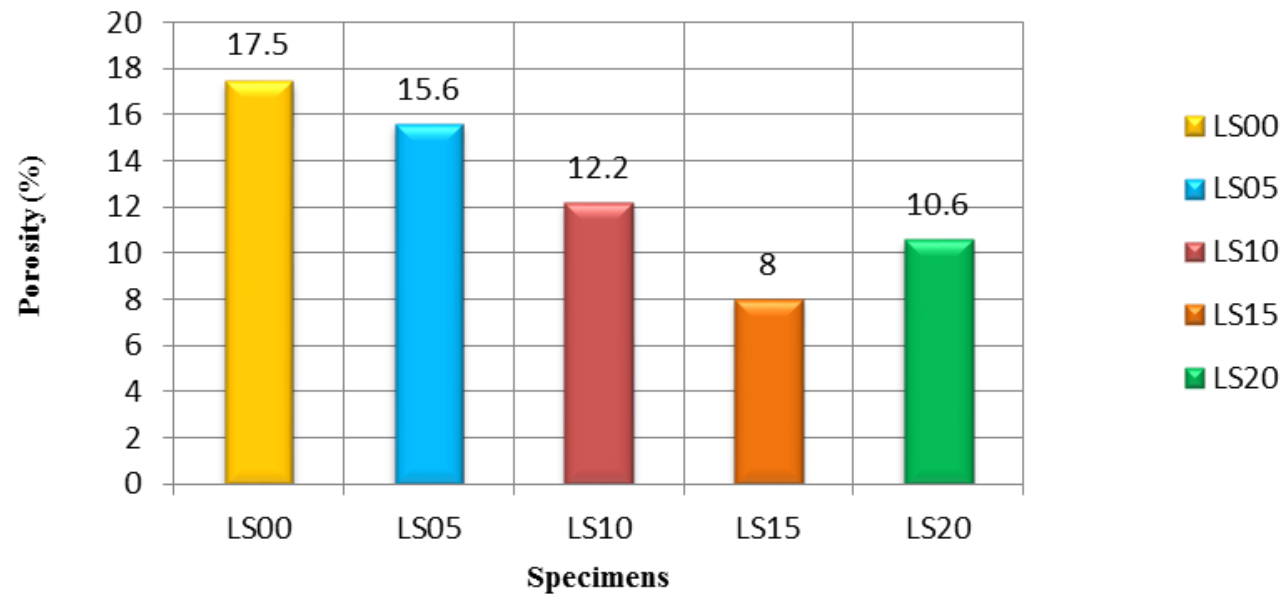

Figure 7. Porosity Value

\subsection{Resistance to Crushing or Dry Compression}

It is expressed as the limit load per unit area that the specimen can withstand without being crushed (Figure 8). It is expressed by the following formula:

$$
R_{c}=\frac{F}{S_{b}}
$$

with $\mathrm{F}$ : maximum load supported by the test piece and $\mathrm{S}_{\mathrm{b}}$ : average gross cross-sectional area of the specimen. 
The results of the compression tests carried out on all samples are given in the figure 8 below; the compression tests were carried out on days 7,14 and 28 for each composition.

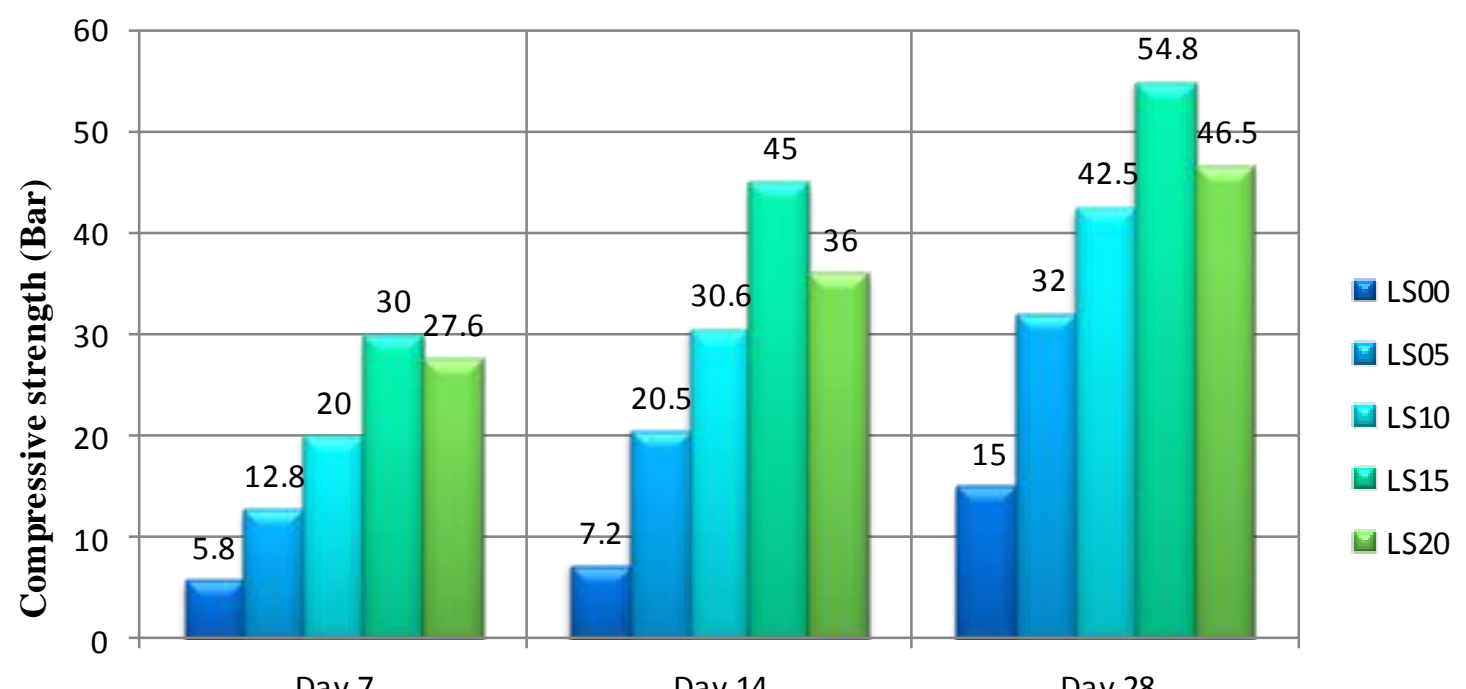

Duration (day)

Figure 8. Change in Dry Compressive Strength

\subsection{Wet Compressive Strength}

The wet compressive strength of investigated laterites is gathered in Table 3.

Table 3: Average wet compressive strength of studied laterites

\begin{tabular}{|c|c|c|c|c|c|}
\hline \multirow{2}{*}{$\begin{array}{c}\text { Duration } \\
\text { (day) }\end{array}$} & \multicolumn{5}{|c|}{ Wet compressive strength (bar) } \\
\cline { 2 - 6 } & LS00 & LS05 & LS10 & LS15 & LS20 \\
\hline Day 7 & Disaggregation & Disaggregation & Disaggre gation & Disaggre gation & Disaggregation \\
\hline Day 14 & Disaggregation & Disaggregation & 4.8 & 8.5 & 8.5 \\
\hline Day 28 & Disaggregation & 4.2 & 6.0 & 18.0 & 10.0 \\
\hline
\end{tabular}

\subsection{Resistance to Traction}

The limit load per unit cross-section that the material can support without breaking is given in figure 9. It can be deduced from the compressive strength by the formula:

$$
R_{t}=\frac{1}{10} R_{c}
$$

with $\mathrm{R}_{\mathrm{t}}$ : Resistance to traction and $\mathrm{R}_{\mathrm{c}}$ : Resistance to compression. 


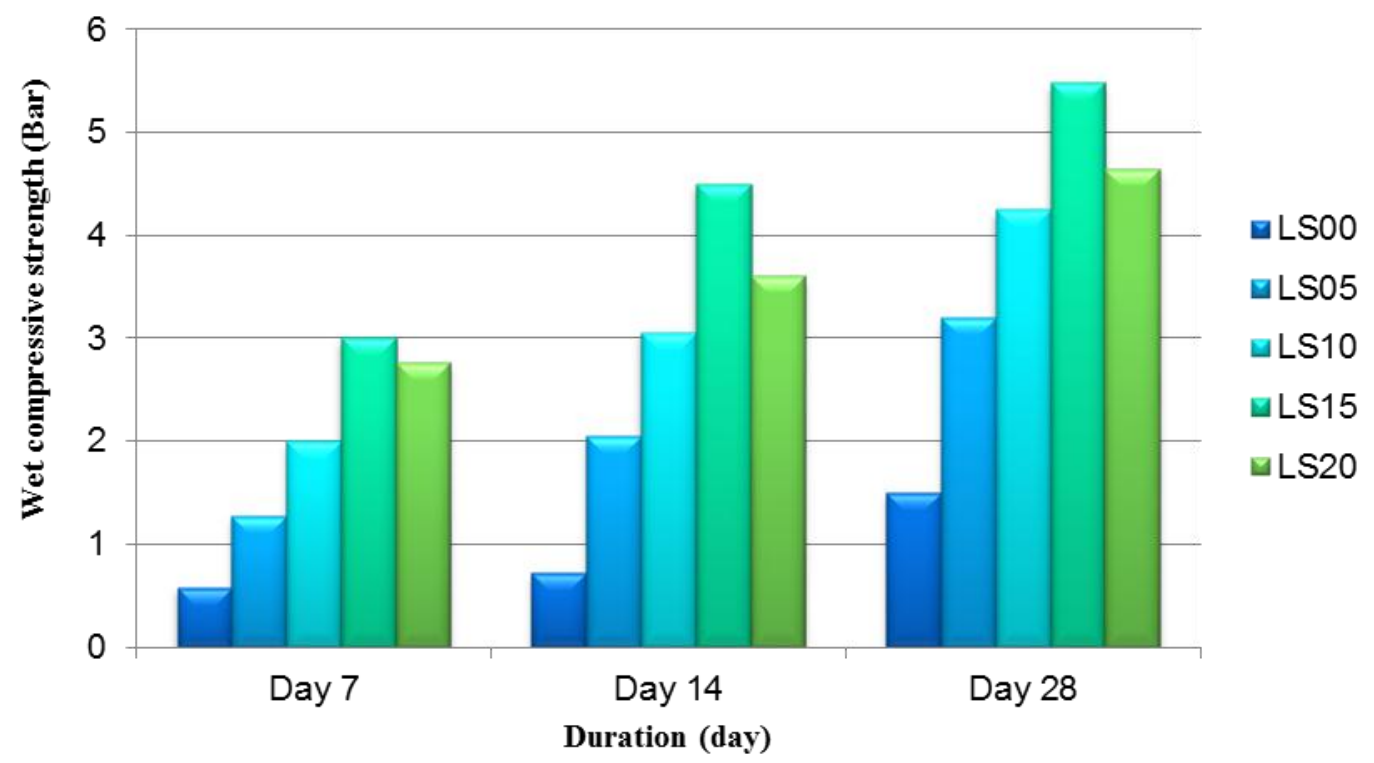

Figure 9. Variation of Tensile Strength

\subsection{Resistance to Shear}

This is the conventional load corresponding to the failure of the specimen subjected to a bending test (figure 10). It is deduced from the compressive strength by the following formula:

$$
R_{s h}=\frac{10}{3} R_{c}
$$

with $\mathrm{R}_{\mathrm{sh}}$ : Resistance to shear and $\mathrm{R}_{\mathrm{c}}$ : Resistance to compression.

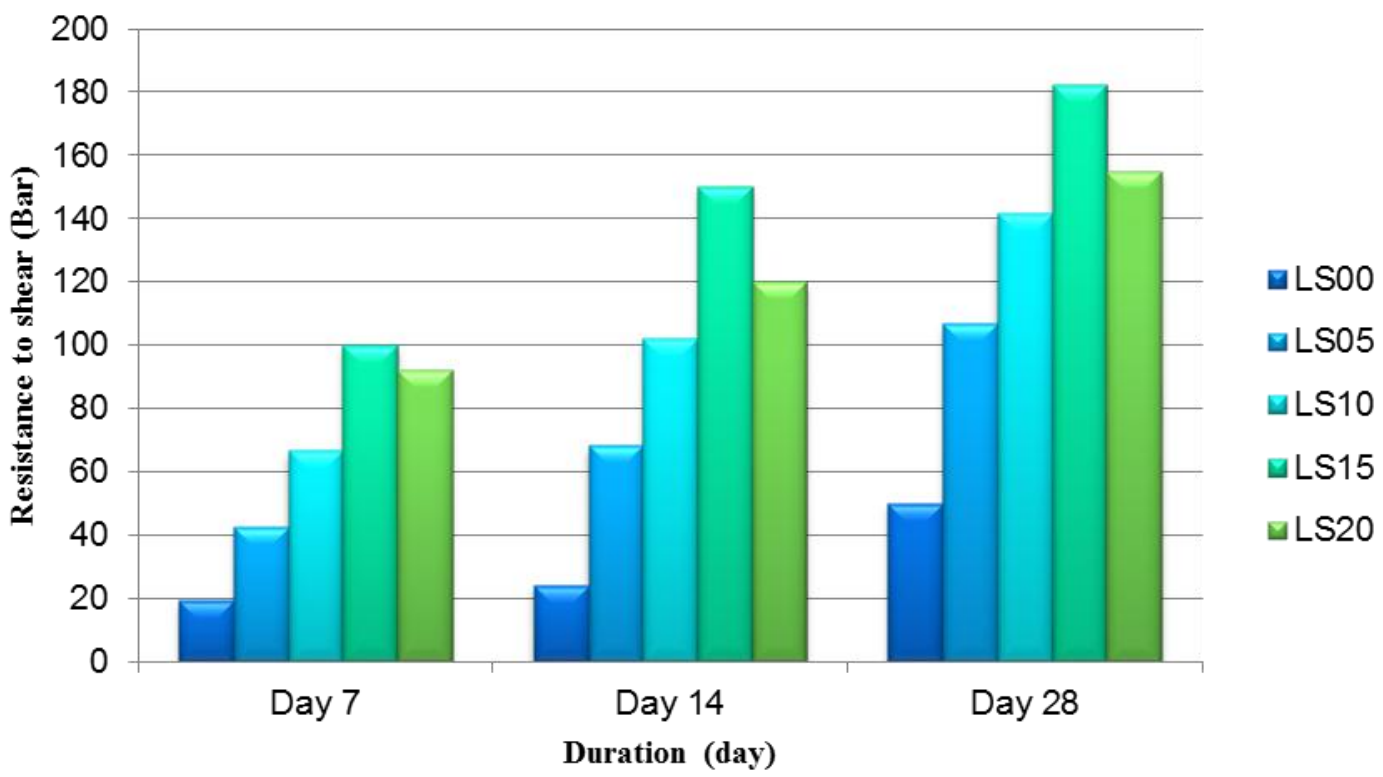

Figure 10. Variation of the Resistance to Shear 


\subsection{Determination of Density}

Density is the ratio of the total mass of a certain amount of soil to its volume. It is expressed by the following formula:

with

$$
\rho=\frac{M}{V}
$$

$\mathrm{M}=$ Total mass

$\mathrm{d}=$ specimen diameter

$\mathrm{h}=$ specimen height

The density of the finished products was measured on day 28 . The results of the measurements are shown in the following figure 11.

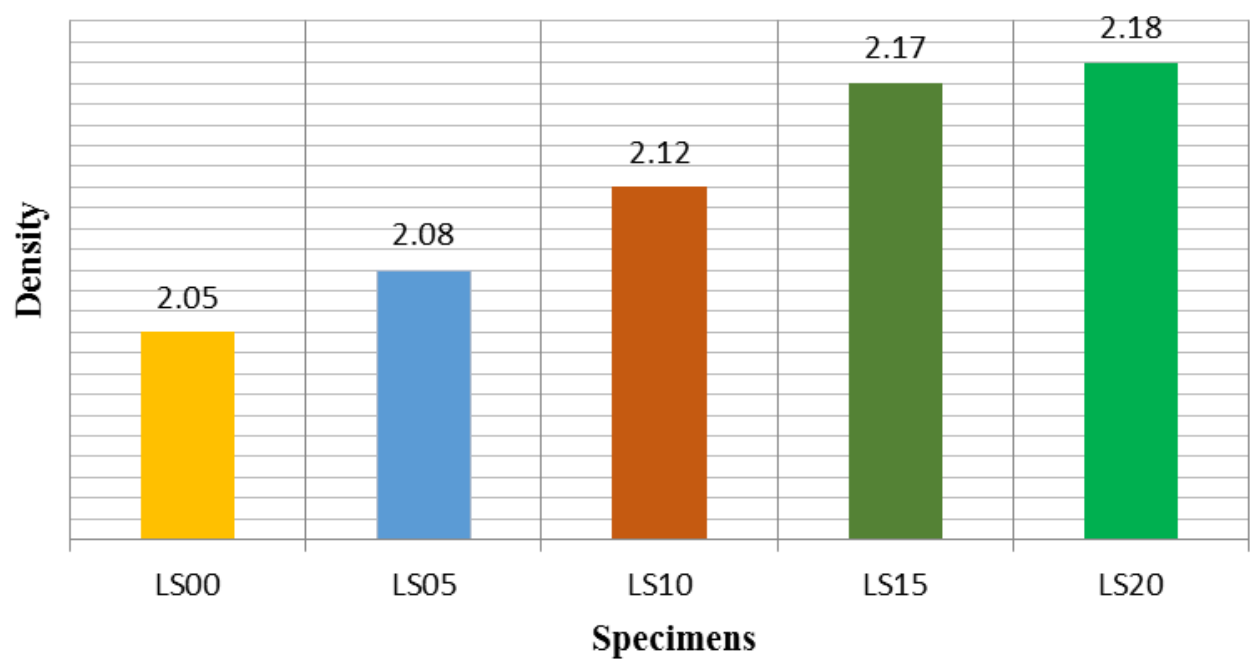

Figure 11. Variation of the Density

This research is dedicated to the valorization of the Malagasy ancestral construction materials not yet referenced, and then to qualify the physical state of the specimens was done by referring to the Cameroonian standards (Table 4). Referring to the Cameroonian standards, the $15 \%$ starch sample with laterite $85 \%$ is in class B "Good", it has a high dry and wet compressive strength compared to the other samples. Samples LS05, LS10, LS20 are in class C "Average", concerning the values of porosity, dry compressive strength and wet compressive strength. Sample LS00 is in class D: "Low". It does not resist after 30 minutes of immersion. After the various manufacturing tests, we were able to determine the best composition of our sample; it is $15 \%$ starch with $85 \%$ laterite. We found that the resistance to dry compression is 54.8 bars; we also know that the resistance to wet compression is 18 bars. During the manufacturing trial, there is the rotting time of 10 days to get the plasticity of the mixture and its homogeneity to obtain the high compressive strength. In the chemical stabilization, we must emphasize that the microbial reduction during the rotting time contributes to the mechanical stabilization of laterites. 
Table 4. Classification of Specimens According to Cameroonian Standards

\begin{tabular}{|c|c|c|c|c|c|c|}
\hline $\begin{array}{l}\text { Characterist } \\
\text { ics }\end{array}$ & $\begin{array}{c}\mathrm{S} \\
\text { (age) }\end{array}$ & $\begin{array}{c}\mathrm{U} \\
\text { (unit) }\end{array}$ & $\begin{array}{l}\text { Class A: } \\
\text { Excellent }\end{array}$ & $\begin{array}{l}\text { Class B: } \\
\text { Good }\end{array}$ & $\begin{array}{l}\text { Class C: } \\
\text { Medium }\end{array}$ & Class D: Low \\
\hline \multirow{2}{*}{$\begin{array}{l}\text { Total } \\
\text { absorption : } \\
\mathrm{p} \\
\text { (24 hours } \\
\text { dipping) }\end{array}$} & \multirow{2}{*}{$\begin{array}{c}28 \\
\text { days }\end{array}$} & \multirow{2}{*}{$\begin{array}{c}\% \\
\text { weight }\end{array}$} & $<5 \%$ & {$[5,10]$} & {$[10,20]$} & $>20$ \\
\hline & & & & $\begin{array}{l}\mathrm{LS} 15: \\
\mathrm{p}=8 \%\end{array}$ & $\begin{array}{l}\text { LS05: } \\
p=15.6 \\
\text { LS } 10: \\
p=12.2 \\
\text { LS20: } \\
p=10.6\end{array}$ & $\begin{array}{l}\text { LS00 : } \\
\text { Disaggregatio } \\
\mathrm{n}\end{array}$ \\
\hline \multirow{2}{*}{$\begin{array}{l}\text { Dry } \\
\text { compressive } \\
\text { strength: } \\
\mathrm{R}_{\mathrm{C}}{ }^{\text {dry }}\end{array}$} & \multirow{2}{*}{$\begin{array}{c}28 \\
\text { days }\end{array}$} & \multirow[t]{2}{*}{ bar } & $>120$ & {$[50,120]$} & {$[20,50]$} & $<20$ \\
\hline & & & & $\begin{array}{l}\mathrm{LS} 15: \\
\mathrm{R}_{\mathrm{c}}=54.8\end{array}$ & $\begin{array}{l}\text { LS05: } \\
R_{c}=32 \\
\text { LA10 : } \\
R_{c}=42.5 \\
\text { LA20 : } \\
R_{c}=46.5\end{array}$ & $\begin{array}{l}\mathrm{LS} 00: \\
\mathrm{R}_{\mathrm{c}}=15\end{array}$ \\
\hline \multirow{2}{*}{$\begin{array}{l}\text { Wet } \\
\text { compressive } \\
\text { strength: } \\
\mathrm{R}_{\mathrm{C}}{ }^{\text {wet }} \\
\text { (24 hours } \\
\text { dipping) }\end{array}$} & \multirow{2}{*}{$\begin{array}{c}28 \\
\text { days }\end{array}$} & \multirow[t]{2}{*}{ bar } & $>20$ & {$[10,20]$} & {$[5,10]$} & $<5$ \\
\hline & & & & $\begin{array}{l}\text { LS15: } \\
\mathrm{R}_{\mathrm{c}}=18\end{array}$ & $\begin{array}{l}\mathrm{LS} 05: \\
\mathrm{R}_{\mathrm{c}}=5.2 \\
\mathrm{LS} 10: \\
\mathrm{R}_{\mathrm{c}}=6 \\
\mathrm{LS} 20: \\
\mathrm{R}_{\mathrm{c}}=10\end{array}$ & $\begin{array}{l}\text { LS00 : } \\
\text { Disaggregatio } \\
\mathrm{n}\end{array}$ \\
\hline
\end{tabular}

\subsection{Comparison of Brick Manufacturing Process}

Table 5. Comparison between Two Bricks from Two Manufacturing Processes

\begin{tabular}{|l|l|l|}
\hline Method of manufacture & $\begin{array}{l}\text { Clay brick stabilized with } \\
\text { starch }\end{array}$ & Terracotta brick \\
\hline Raw materials & Cassava, laterite & Clay \\
\hline Fuel & No cooking & Wood fuels (biomass) \\
\hline Advantages of the method & $\begin{array}{l}\text { Available products } \\
\text { to farmers, bets easy work }\end{array}$ & $\begin{array}{l}\text { Bons comportements à l'eau, } \\
\text { utilisation simple avec la } \\
\text { moule. }\end{array}$ \\
\hline Cooking temperature & $\begin{array}{l}\text { Heating to } 95^{\circ} \mathrm{C} \text { for cassava } \\
\text { starch }\end{array}$ & $1200^{\circ} \mathrm{C}$ for brick firing \\
\hline $\begin{array}{l}\text { Mechanical resistance at 28 } \\
\text { days }\end{array}$ & 54.8 bars & 27.3 bars \\
\hline Sustainability & Bricks do not show cracks & $\begin{array}{l}\text { Bricks are more easily } \\
\text { exposed to cracks. }\end{array}$ \\
\hline $\mathrm{CO}_{2}$ emissions & $\begin{array}{l}\text { The brick emits a low level } \\
\text { of } \mathrm{CO}_{2}\end{array}$ & $\begin{array}{l}\text { The brick emits a high level } \\
\text { of } \mathrm{CO}_{2} \text { during firing. }\end{array}$ \\
\hline
\end{tabular}

According to the comparison of used methods, the laterite brick stabilized with starch is easy to manufacture, does not pollute the atmosphere, and respects the environment. 


\subsection{Environmental Approach}

\section{a. Socio-economic Impacts}

- Creation of decent work for villagers by recruiting local labor ;

- Improvement of accessibility to goods and services;

- Valorization of available and accessible local products.

If such an activity could be formalized as a source of income, then environmental protection would be better managed. And since it is a source of income, the villagers will be able to send their children to school, to consult a doctor and to buy medicines if they are sick.

\section{b. Negative Impacts during Manufacturing}

- Laterite excavation from mining;

- Disturbance and accident due to laterite extraction holes;

- Pollution with unused material and waste;

- Need to manufacture starch from dry cassava;

- Heating of starch before use.

\section{c. Mitigation of Negative Impacts}

Mitigation measures must be taken to ensure that negative impacts are mitigated and perhaps even reversed, such as:

- Compliance with work safety rules;

- Sensitization of brick craftsmen to environmental protection;

- Management of liquid pollutants and solid waste;

- Installation of a starch production unit;

- Management of unused materials;

- Cheaper choice of fuel for heating starch by recycling cassava peels for a green and circular economy;

- Planting cassava over larger areas.

This process, simple in its steps and practice, should be popularized among artisanal brick makers.

The inclusion of this concept and the manufacture of artisanal cement [12] in the training program in technical or vocational schools is essential for a country like Madagascar. Indeed, over the years, cement and lime have been the main materials used for stabilizing soils. By definition, soil modification is the addition of a modifier like cement or lime to a soil to change its index properties, while soil stabilization is the treatment of soils to enable their strength and durability to be improved such that they become totally suitable for construction beyond their original classification. The modifier materials have rapidly increased in price due to the sharp increase in the cost of energy and their high demand. It has been also shown that Portland cement, by the nature of its chemistry, produces large quantities of $\mathrm{CO}_{2}$ for every ton of its final product which contributes to the melting of the ozone layer covering the earth surface. Therefore, replacing proportions of the Portland cement in soil stabilization with Cassava starch will reduce the overall environmental impact of the stabilization process [12, 13].

In both Africa and Madagascar, it was reported that the use of alternative raw materials could help to bring the opportunity to solve many socio-economic problems [14-16]. This is particularly the case of Gbado-Lite city (Nord-Ubangi Province) in Democratic Republic of the Congo where lateritic soil is widely used as Brick Manufacturing raw material [1]. The present study revealed thus that Manihot esculenta Crantz could help people to combat deforestation linked to the process of clay brick manufacturing in Nord-Ubangi eco-region which is a subgroup of Northeastern Congolian lowland forests. This eco-region displaying a climate better adapted to the cassava culture, is one of the 200 globally priority terrestrial ecoregions known as the "G200" [17-21]. 


\section{Conclusion and Suggestion}

The aim of this work was to study the stabilization of laterite by starch in order to develop a new process for laterite stabilization, without cement or fat lime and at lower cost using cassava. According to the laboratory test results, it was proved that the value of the dry compressive strength of the test specimens (samples) carried out gave a higher result of 54.8 bars (85\% laterite with $15 \%$ starch) confirming thus that new materials can be produced in the field of civil engineering. The stabilization of laterite by starch is a very interesting choice because cassava is cultivated in all regions of Madagascar, and it is also technically, economically leading compared to other stabilizers, and environmentally feasible for sustainable development.

Further in-depth studies are still necessary, in particular, the implementation of large scale trials to be able to conclude on the reliability of this method. The protection of the environment is a vital duty worldwide, so it is important to raise public awareness.

\section{Acknowledgement}

The authors are indebted to the Polytechnic High School, the University of Gbado-Lite and the University of Kinshasa (Democratic Republic of the Congo) for their technical assistance.

\section{References}

1. Ngbolua KN, Falanga CM, Djoza RD, Masengo CA, Gamo AN, Bongo GN, Gbolo BZ, Virima M, Mpiana PT. Socio-economic and Environmental Impacts of Clay Brick Manufacturing in Gbado-Lite City (Nord Ubangi Province, DR Congo). Journal of Environment Protection and Sustainable Development, 2019; 5(3):126-131

2. Ng CWW, Akinniyi DB, Zhou C. Experimental study of the hydro-mechanical behaviour of compacted lateritic sandy lean clay. Revue Canadienne de Géothecnique, 2019; 1-9. https://doi.org/10.1139/cgj-2019-0301.

3. Ng CWW, Akinniyi DB, Zhou C, Chiu CF. Comparisons of weathered lateritic, granitic and volcanic soils: Compressibility and shear strength. Engineering Geology, 2019; 249: 235-240.

4. Osinubi KJ, Nwaiwu CM.Design of compacted lateritic soil liners and covers. Journal of Geotechnical and Geoenvironmental engineering, 2006; 132(2): 203-213.

5. Otalvaro IF, Neto MPC, Caicedo B. Compressibility and microstructure of compacted laterites. Transportation Geotechnics, 2015; 5:20-34.

6. Gui MW, Yu CM. Rate of strength increase of unsaturated lateritic soil. Canadian Geotechnical Journal, 2008; 45(9):1335-1343.

7. Larrahondo JM, Burns SE. Laboratory-prepared iron oxide coatings on sands: surface characterization and strength parameters. Journal of Geotechnical and Geoenvironmental Engineering, 2013; 140(4):04013052.

8. Malagasy National Institute of Statistics, Antananarivo, Madagascar, 2018.

9. Daouda S, Aboubakar S, Ezoua P, Kouame C, Dally L.I., Kati-Coulibaly S. Comportement hydrothermique des amidons de 4 variétés de manioc (Manihot esculenta Crantz) cultivées en Côte d'Ivoire. International Journal of Biological and Chemical Sciences, 2009; 3(6): 1467-1479.

10. Vernier P, N'Zué B, Zakhia-Rozis N. Le manioc, entre culture alimentaire et filière agroindustrielle. Éditions (CQuæ, CTA, Presses agronomiques de Gembloux, 2018. ISBN (Quæ) : 978-2-7592-2708-2 ISBN CTA : 978-92-9081-620-1 ISBN (PAG) : 978-2-87016-1531 ISSN : 1778-6568. 
11. Muhammad HR, Anwar K, Sajjad A. Evaluation of sustainable clay bricks incorporating Brick Kiln Dust. Journal of Building Engineering, 2019; 24:100725. https://doi.org/10.1016/j.jobe.2019.02.017.

12. Ravelomanantsoa S, Razanajatovo HO, Randriana NR, Randriamalala TR, Baofiza, Rakotonomenjanahary DE, Matondo A, Ngbolua KN, Baholy RR. Physicochemical and Mechanical Characterization of Pseudo-artisanal Cement Made in Madagascar. International Journal of Materials Chemistry and Physics (in press).

13. Adefemi AB, Adebayo IJ, Ayodele H. Stabilization of Lateritic Soil with Cassava Peels Ash. British Journal of Applied Science \& Technology, 2015; 7(6): 642-650.

14. Rakotoarison S, Rasolomanana EH, Baholy RR, Ngbolua KN. Bemolanga tar sand: A local raw material for tarring roads in Madagascar. International Journal of Innovation and Scientific Research, 2016; 24(2):397-406.

15. Rakotoarison S, Rasolomanana EH, Baholy RR, Ngbolua KN. Physicochemical characterization of the non-conventional petroleum oil fossil products from Bemolanga and Tsimiroro, Madagascar. International Journal of Innovation and Scientific Research, 2016; 24(2):423-427.

16. Razafindramanga AW, Ngbolua KN, Bongo GN, Baholy RR. Laboratory Testing on the Promotion of Madagascar's Industrial Waste and Natural Materials as Clinker Mineralizers. Asian Journal of Geological Research, 2019; 2(2): 1-13.

17. Ngbolua KN, Zuangbo I, Molongo M, Masengo AC, Djolu DR, Yabuda H, Bongo NG, Gbolo ZB, Monde-te-Kazangba G Effect of Agricultural Residues BasedCompost on the Yield of Amaranthus hybridus L. (Amaranthaceae) in Gbado-Lite City, Nord-Ubangi (Democratic Republic of the Congo). Budapest International Research in Exact Sciences (BirEx) Journal, 2019; 1(4): 53-61.

18. Ngbolua KN, Kumbali NG, Mbembo-wa-Mbembo B, Djolu DR, Bongo NG Falanga MC, Gbolo ZB, Masengo AC, Libwa MTB. Epidemio-therapeutic Survey on Malnourished Children Aged 0-5 Years Old in the Gbado-Lite Health Zone (Nord Ubangi Province, Democratic Republic of the Congo). Britain International of Exact Sciences (BIoEx) Journal, 2019; 1(1): 22-28.

19. Ngbolua KN, Kumbali NG Mbembo-wa-Mbembo B, Kohowe PS, Kogana KF, Bongo NG, Masengo AC, Djolu DR. First Report on Three Cases of Monkey pox in Nord Ubangi Province (Democratic Republic of the Congo). Britain International of Exact Sciences (BIoEx) Journal, 2020; 2(1): 120-125.

20. Ngbolua KN, Ngemale GM, Masengo AC, Ndolete GJP, Bongo NG, Ndanga BA, Tshibangu DST, Tshilanda DD. Survey on the Sale of Megaphrynium Macrostachyum (Marantaceae) Leaves in Gbado-Lite City and Surroundings (Nord Ubangi Province, Democratic Republic of the Congo). Budapest International Research in Exact Sciences (BirEx) Journal, 2020; 2(2): 157-167.

21. Ngunde-te-Ngunde S, Lengbiye ME, Tshidibi DJ, Kengo VF, Djolu DJ, Masengo AC, Gbolo ZB, Iteku BJ, Mpiana PT, Ngbolua KN. Antisickling and Antibacterial Activities of Anthocleista schweinfurthii Gilg. (Gentianaceae) from Nonhuman Primates Pharmacopoeia in Democratic Republic of the Congo. Budapest International Research in Exact Sciences, 2019; 1(3): 14-20. 